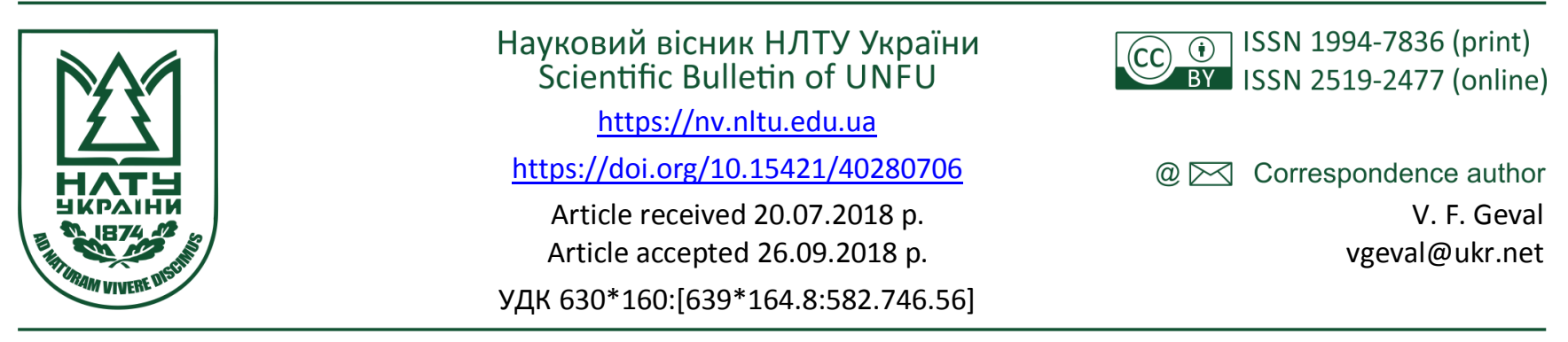

В. Ф. Гевал1, М. М. Гузь' ${ }^{1}$ В. І. Баранов ${ }^{2}$

${ }^{I}$ Національний лісотехнічний університет Украӥни, м. Львів, Украӥна

2 Львівський національний університет ім. Івана Франка, м. Львів, Украйна

\title{
БІОХІМІЧНІ ПОКАЗНИКИ ЖИТТЄДІЯЛЬНОСТІ НАСІННЯ ГІРКОКАШТАНІВ, НАЙПОШИРЕНІШИХ У ЗАХІДНОМУ РЕГІОНІ УКРАЇНИ
}

\begin{abstract}
Визначено біохімічні показники життєдіяльності насіння гіркокаштанів для пошуку стійких проти каштанової мінуючої молі (Cameraria ohridella Desch. \& Dem (Lepidoptera, Gracillariidae)) видів і форм. Для експериментів у насінний рік в умовно чистих зонах і в місцях інтенсивного антропогенно-техногенного забруднення відібрано насіння чотирьох видів гіркокаштанів. Заготівлю насіння здійснено способом збирання із поверхні землі у період найінтенсивнішого його опадання. Досліджено вміст у насінні гіркокаштанів низки фізіолого-біологічних, морфологічних та основних біохімічних показників (білка, розчинних вуглеводнів і "сирого жиру"), золи, макро- і мікроелементів в умовно чистих зонах і в місцях інтенсивного антропогенно-техногенного забруднення. Встановлено рівень активності перекисного окислення ліпідів (ПОЛ) та вміст відновленого глутатіону. Вивчені зміни фізіолого-біологічних та біохімічних показників свідчать, що порівняно із трьома іншими досліджуваними видами дерева гіркокаштана кінського звичайного у стресових грунтово-кліматичних умовах великого міста 3 додатковим зниженням життєздатності каштановою мінуючою міллю характеризуються найбільшими негативними змінами у метаболізмі. Це свідчить, що за зростання в аналогічних грунтово-кліматичних умовах та за подібного навантаження чинників антропогенно-техногенного впливу, дерева і насадження жовтоквіткового (Aesculus octandra Marsh.) i червоноквіткових видів гіркокаштанів (Aesculus pavia L. i Aesculus carnea Hayne) на сьогодні є життєво стійкішими, ніж дерева і насадження найпоширенішого у регіоні гіркокаштана кінського звичайного (Aesculus hippocastanum L.).
\end{abstract}

Ключові слова: гіркокаштани; фізіолого-біологічні, морфологічні та основні біохімічні показники насіння; вміст мікро- $\mathrm{i}$ мікроелементів; негативні зміни у метаболізмі.

Вступ. Деревні рослини видів Гіркокаштанів інтродуковано в Україні, є унікальними індикаторами екологічних умов і стану забруднення навколишнього середовища. Вони виконують важливу екосферну функцію, $\epsilon$ універсальними природними фільтрами очищення грунту, повітря та води від техногенних забруднень, мають вагоме архітектурне, лікувальне та лісівниче значення. Але стан гіркокаштанових насаджень у містах та інших населених пунктах нашої країни катастрофічно погіршується внаслідок несприятливої дії промислових газів, автотранспортних викидів, важких металів, посухи, засолення, високих температур повітря, шкідників і хвороб тощо. У Західному регіоні України у різних видах і типах зелених насаджень найпоширеніші чотири види гіркокаштанів: кінський звичайний, павія, восьмитичинковий та червоноквітковий або м'ясо-червоний.

Погіршення стану дерев і насаджень стосується насамперед найпопулярнішого і найпоширенішого у нашій країні виду - гіркокаштана кінського звичайного.

Об'єкти та методика дослідження. Об'єкт дослідження - дерева чотирьох видів гіркокаштанів у зелених насадженнях різних видів і типів у Західному регіоні України.
Предмет дослідження - біохімічні показники насіння гіркокаштанів кінського звичайного, павія, восьмитичинкового та червоноквіткового, або м'ясо-червоного.

Мета дослідження - встановити біохімічні показники насіння найпоширеніших у Західному регіоні України видів гіркокаштанів та визначити за ними стійкі проти каштанової мінуючої молі види і форми гіркокаштанів.

Як відомо, із багатьох видів родини Гіркокаштанових в Україні найчастіше для озеленення вулиць міст і сіл використовують рослини гіркокаштана кінського звичайного. Загальна чисельність дерев цього гіркокаштана у країні сягає багатьох мільйонів особин (Біологія каштанів). Проте останнім часом, починаючи з 2000 р., внаслідок ураження каштановою мінуючою міллю (Саmeraria ohridella Deschka et Dimic) листя дерев виду вже в середині, або навіть на початку літа інтенсивно жовтіють й опадають, втрачаючи при цьому декоративність і біологічну стійкість (Akimov \& Zerova 2003; Akimov et al., 2003, 2006; Heval \& Huz, 2012; Hryhoriuk et al., 2004; Kramarets, 2005; Kramarets \& Kurochka, 2006). Додатковим негативним чинником зниження біологічної стійкості дерев і насаджень гіркокаштана кінського зви-

\section{Інформація про авторів:}

Гевал Володимир Федорович, здобувач, кафедра лісових культур і лісової селекції. Email: vgeval@ukr.net

Гузь Микола Михайлович, д-р с.-г. наук, професор, завідувач кафедри лісових культур і лісової селекції. Email: mguz@ukr.net

Баранов Володимир Іванович, канд. біол. наук, доцент, кафедра фізіології рослин. Email: baranovlwiw@gmail.com

Цитування за ДСту: Гевал В. Ф., Гузь М. М., Баранов В. І. Біохімічні показники життєдіяльності насіння гіркокаштанів, найпоширеніших у західному регіоні України. Науковий вісник НлтУ України. 2018, т. 28, № 7. С. 31-35.

Citation APA: Geval, V. F., Huz, M. M., \& Baranov, V. І. (2018). Biochemical indicators of vitality of the seeds of horse chestnut, common in the western region of Ukraine. Scientific Bulletin of UNFU, 28(7), 31-35. https://doi.org/10.15421/40280706 
чайного є вплив викидів автотранспорту, осідання пилу на листках і т.ін., наслідком чого є зниження здатності дерев до перезимування, а їх насіння до проростання (Hryhoriuk et al., 2004). Останнє може призвести до втрати всієї популяції цього виду в Україні.

На сьогодні єдиним реально дієвим і найефективнішим засобом боротьби 3 каштановою мінуючою міллю $\epsilon$ ін'єкції речовинами - інгібіторами росту комах у стовбури і гілки дерев, або у грунт прикореневої зони. Проте масове застосування цього заходу стримується через високу ціну препаратів - вартість одної ін'єкції сягає 15-20 дол. США. При цьому на одне дерево віком 5070 років і більше потрібно зробити мінімум 3-4 ін'єкції 3 терміном дії препарату 3-5 років.

Більш дієвим заходом збереження насаджень гіркокаштана кінського звичайного, на нашу думку, є пошук стійких проти каштанової мінуючої молі видів і форм, зокрема і за біохімічними показниками, які можуть бути індикаторами стійкості рослин (Liashenko, Shupranova \& Vinnychenko, 2005; Filonik, Zamoruieva \& Kysla, 2010; Demchuk, Hryhoriuk \& Kolomiiets, 2011; Yavorovskyi, 2011).

Для визначення таких біохімічних показників ми здійснили низку досліджень 3 відповідними аналізами насіння досліджуваних видів гіркокаштанів. Для проведення експериментів відібрали насіння чотирьох видів гіркокаштанів дерева і насадження яких ростуть в умовно чистих зонах і в місцях інтенсивного антропогеннотехногенного забруднення Західного регіону України.

За умовно чисті зони прийняли парк культури і відпочинку ім. Б. Хмельницького у Львові й парк смт Гоща Рівенської обл. У цих парках восени, у насінний для усіх видів гіркокаштанів рік, зібрали плоди для експериментальних досліджень, які й прийняли як контроль. Для цього у парку ім. Б. Хмельницького заготовляли плоди гіркокаштанів кінського звичайного, павія i м'ясо-червоного, а у парку смт Гоща - гіркокаштана восьмитичинкового. Такий територіальний розбіг об'єктів був вимушеним через відсутність дерев усіх зазначених видів в одному місці зростання.

Насіння гіркокаштанів із зон антропогенно-техногенного забруднення заготовляли у насінні роки у вуличних насадженнях Львова, у місцях, яким притаманний інтенсивний рух автомобільного транспорту- до
5000-10000 і більше автомобілів за добу (гіркокаштан кінський звичайний - на проспекті Свободи, павія - на вул. 700-річчя Львова, восьмитичинковий - на вул. Науковій і м'ясо-червоний - на вул. Замарстинівській).

Заготівлю насіння проводили способом збирання із поверхні землі у період найінтенсивнішого його опадання. Після заготівлі очищували насіння від домішок і відходів за вимогами ДСТУ 5036:2008 (DSTU 5036:2008) та рекомендаціями 3 лісового насінництва щодо визначення посівних якостей насіння деревних видів (Debryniuk et al., 1998).

Масу свіжозібраного для експериментів насіння i абсолютно суху масу після висушування за температури $105^{\circ} \mathrm{C}$ до постійної маси визначали зважуванням на електронній вазі Mettler PM 46003 точністю до 0,01 г. Аналіз золи проводили після спалювання насіння у муфельній печі за температури $450{ }^{\circ} \mathrm{C}$. Визначення "сирого" жиру проводили методом Рушковского за попередньої екстракції петролейним ефіром, з наступним обробітком сірчаним ефіром в апараті Сокслета, після чого наважку в пакеті висушували за температури $105^{\circ} \mathrm{C}$ (Ermakov, 1972). Визначення вмісту калію, кальцію і натрію проводили методом полум'яної фотометрії на фотометрі типу ПФМ-3ОМЗ (Peterburhskyi, 1968; BSh2.850.012TO, 1974). Вміст білка визначали за допомогою реактиву Бредфорда, відновлений глютатіон - за методом Гришко 3 використанням реактиву Елмана (Grishko \& Syshhikov, 2012), перекисне окислення ліпідів (ПОЛ) - методом Лея, Кассиди (Musiienko, Parshykova \& Slavnyi, 2001).

Результати дослідження. Iз літературних джерел відомо, що червоно- і жовтоквіткові види гіркокаштанів не вражає мінуюча міль (Hryhoriuk et al., 2004; Heval \& Huz, 2012), тому важливо вивчити біохімічні показники насіння цих видів порівняно із гіркокаштаном кінським звичайним.

На початкових етапах дослідження визначено низку морфологічних показників, таких як: нативна й абсолютно суха маса насіння досліджуваних видів гіркокаштанів та основні біохімічні показники - вміст білка, розчинних вуглеводнів і "сирого" жиру, які визначають сутність готовності насіння до перебування у стані спокою у зимовий період і до майбутнього проростання (табл. 1).

\begin{tabular}{|c|c|c|c|c|c|}
\hline \multirow{3}{*}{ Вид гіркокаштана } & \multirow[b]{2}{*}{$\begin{array}{c}\text { Нативна маса } \\
\text { насіння, г }\end{array}$} & \multirow[b]{2}{*}{$\begin{array}{c}\text { Абсолютно } \\
\text { суха маса, \% }\end{array}$} & \multicolumn{3}{|c|}{ Вміст } \\
\hline & & & $\begin{array}{l}\text { "сирого" жиру, в \% на } \\
\text { абсолют но суху масу }\end{array}$ & $\begin{array}{c}\text { вуглеводів, мг/100 г } \\
\text { сирої маси }\end{array}$ & $\begin{array}{l}\text { білка, мг/100 г } \\
\text { сирої маси }\end{array}$ \\
\hline & $\mathrm{M}^{ \pm \mathrm{m}}$ & $\mathrm{M}^{ \pm \mathrm{m}}$ & $\mathrm{M}^{ \pm \mathrm{m}}$ & $\mathrm{M}^{ \pm \mathrm{m}}$ & $\mathrm{M}^{ \pm \mathrm{m}}$ \\
\hline \multicolumn{6}{|c|}{ Умовно чиста зона } \\
\hline Гіркокаштан кінський звичайний & $16,89^{ \pm 0,66}$ & $44,6^{ \pm 1,2}$ & $26,5^{ \pm 1,9}$ & $118,5^{ \pm 4,0}$ & $245,0^{ \pm 0,1}$ \\
\hline Гіркокаштан восьмитичинковий & $7,43^{ \pm 0,42}$ & $46,7^{ \pm 0,8}$ & $27,2^{ \pm 1,5}$ & $113,5^{ \pm 6,0}$ & $210,0^{ \pm 0,2}$ \\
\hline Гіркокаштан павія & $10,55^{ \pm 0,5}$ & $51,3^{ \pm 1,4}$ & $23,6^{ \pm 1,6}$ & $103,3^{ \pm 5,0}$ & $310,0^{ \pm 0,8}$ \\
\hline Гіркокаштан м'ясо-червоний & $24,22^{ \pm 0,98}$ & $38,9^{ \pm 0,9}$ & $25,8^{ \pm 0,7}$ & $136,2^{ \pm 2,0}$ & $210,0^{ \pm 0,5}$ \\
\hline \multicolumn{6}{|c|}{ Техногенно-антропогенно забруднена зона } \\
\hline Гіркокаштан кінський звичайний & $15,43^{ \pm 0,29}$ & $42,7^{ \pm 1,3}$ & $27,3^{ \pm 1,6}$ & $92,8^{ \pm 3,0}$ & $216,0^{ \pm 0,9}$ \\
\hline Гіркокаштан восьмитичинковий & $7,16^{ \pm 0,23}$ & $46,3^{ \pm 0,4}$ & $28,7^{ \pm 1,2}$ & $109,4^{ \pm 2,0}$ & $207,0^{ \pm 0,4}$ \\
\hline Гіркокаштан павія & $9,95^{ \pm 0,56}$ & $48,3^{ \pm 2,3}$ & $26,4^{ \pm 1,3}$ & $101,3^{ \pm 3,0}$ & $298,0^{ \pm 2,3}$ \\
\hline Гіркокаштан м'ясо-червоний & $23,12^{ \pm 0,07}$ & $36,6^{ \pm 0,3}$ & $26,7^{ \pm 1,4}$ & $130,2^{ \pm 2,0}$ & $203,0^{ \pm 0,7}$ \\
\hline
\end{tabular}

Встановлено, що в умовах відносно чистої зони максимум нативної маси має насіння гіркокаштана м'ясочервоного. Насіння каштана кінського звичайного займають проміжне місце, а найменшу масу мають насіння гіркокаштанів восьмитичинкового і павія, що загалом відповідає і масі 1000 шт. насінин (табл. 2). За вмістом абсолютно сухої маси отримано майже дзеркально протилежні дані - мінімум маси притаманне насінню каштана м'ясо-червоного, максимум - для каштанів павія і восьмитичинкового. Насіння каштана кінського звичайного знову займає проміжне місце. За масою "сирого" жиру його мінімум був у насінні каштанів 
павія і м'ясо-червоного, максимум - у каштана восьмитичинкового.

Достатньо високі показники вмісту "сирого" жиру пояснюють висушуванням наважок після екстракції в апараті Сокслета не на повітрі, а за температури $105^{\circ} \mathrm{C}$, наслідком чого було видалення води, а показники перераховували на абсолютно суху масу. Вміст розчинних вуглеводів був найменшим у видів павія і восьмитичинкового, а найбільшим - у гіркокаштана м'ясо-червоного. Як і прогнозувалось, вміст білка був зворотним до вмісту жиру. При цьому найбільші відмінності виявлено у каштана кінського звичайного і гіркокаштана павія. В умовах техногенно-антропогенно забруднених зон (вулиці Львова) практично за всіма показниками спостережено їх зменшення. При цьому варто зазначити, що найбільш показово це виражено у насіння гіркокаштана кінського звичайного (див. табл. 2).

Табл. 2. Показники маси насіння гіркокаштанів

\begin{tabular}{|c|c|c|c|c|}
\hline \multirow{2}{*}{ Вид гіркокаштана } & \multicolumn{3}{|c|}{$\begin{array}{c}\text { Маса життєздатної } \\
\text { насінини, г }\end{array}$} & \multirow{2}{*}{$\begin{array}{c}\text { Середня } \\
\text { маса } \\
1000 \text { шт. } \\
\text { насінин, г }\end{array}$} \\
\hline & $\begin{array}{c}\text { міні- } \\
\text { мальна }\end{array}$ & $\begin{array}{c}\text { серед- } \\
\text { ня }\end{array}$ & $\begin{array}{l}\text { макси- } \\
\text { мальна }\end{array}$ & \\
\hline $\begin{array}{c}\text { Гіркокаштан } \\
\text { звичайний }\end{array}$ & 7,8 & 13,2 & 26,9 & 13230 \\
\hline $\begin{array}{l}\text { Гіркокаштан вось- } \\
\text { митичинковий }\end{array}$ & 8,4 & 11,3 & 22,5 & 11300 \\
\hline Гіркокаштан павія & 4,9 & 8,78 & 14,8 & 8785 \\
\hline $\begin{array}{c}\text { Гіркокаштан } \\
\text { м'ясо-червоний }\end{array}$ & 11,7 & 20,2 & 39,3 & 20206 \\
\hline
\end{tabular}

Певною мірою вміст золи і мінеральних елементів можна також віднести до біохімічних показників, тому дослідили їх вміст у насінні досліджуваних видів гіркокаштанов (табл. 3).

Табл. 3. Вміст золи і макроелементів у насінні гіркокаштанів

\begin{tabular}{|c|c|c|c|c|}
\hline \multirow{4}{*}{$\begin{array}{c}\text { Вид } \\
\text { гіркокаштана }\end{array}$} & \multicolumn{4}{|c|}{ Вміст золи і мінеральних елементів } \\
\hline & \multirow[b]{2}{*}{ Зола, \% } & Калій & Кальцій & Натрій \\
\hline & & \multicolumn{3}{|c|}{$\begin{array}{c}\text { у мг на } 100 \text { г } \\
\text { повітряно-сухої маси }\end{array}$} \\
\hline & $\mathrm{M}^{ \pm \mathrm{m}}$ & $\mathrm{M}^{ \pm \mathrm{m}}$ & $\mathrm{M}^{ \pm \mathrm{m}}$ & $\mathrm{M}^{ \pm \mathrm{m}}$ \\
\hline \multicolumn{5}{|c|}{ Умовно чиста зона } \\
\hline $\begin{array}{r}\text { Гіркокаште } \\
\text { звича } \\
\end{array}$ & $3,89^{ \pm 0,6}$ & $45,0^{ \pm 0,9}$ & $739,0^{ \pm 3,4}$ & $62,0^{ \pm 1,4}$ \\
\hline $\begin{array}{r}\text { Гірк } \\
\text { восьмит }\end{array}$ & $5,71^{ \pm 0,8}$ & $69,0^{ \pm 1,4}$ & $1065,0^{ \pm 7,4}$ & $84,0^{ \pm 2,8}$ \\
\hline Гірк & $5,28^{ \pm 0,5}$ & $55,0^{ \pm 0,9}$ & $943,0^{ \pm 5,9}$ & $84,0^{ \pm 3,8}$ \\
\hline $\begin{array}{c}\text { Гіркокаштан } \\
\text { м'ясо-червоний }\end{array}$ & $3,46^{ \pm 0,3}$ & $44,0^{ \pm 1,6}$ & $675,0^{ \pm 7,5}$ & $59,0^{ \pm 2,6}$ \\
\hline \multicolumn{5}{|c|}{ Техногенно-антропогенно забруднена зона } \\
\hline $\begin{array}{c}\text { Гіркокаштан кінський } \\
\text { звичайний }\end{array}$ & $3,32^{ \pm 0,3}$ & $32,0^{ \pm 1,6}$ & $619,0^{ \pm 2,7}$ & $74,0^{ \pm 1,7}$ \\
\hline $\begin{array}{c}\text { Гіркокаштан } \\
\text { восьмитичинковий }\end{array}$ & $5,59^{ \pm 0,6}$ & $61,0^{ \pm 2,2}$ & $988,0^{ \pm 7,1}$ & $87,0^{ \pm 1,2}$ \\
\hline Гіркокаштан павія & $4,82^{ \pm 0,5}$ & $48,0^{ \pm 0,9}$ & $897,0^{ \pm 5,3}$ & $89,0^{ \pm 2,3}$ \\
\hline $\begin{array}{c}\text { Гіркокаштан } \\
\text { м'ясо-червоний }\end{array}$ & $3,16^{ \pm 0,2}$ & $41,0^{ \pm 1,3}$ & $616,0^{ \pm 4,8}$ & $61,0^{ \pm 3,3}$ \\
\hline
\end{tabular}

Встановлено, що вміст золи в умовно чистих зонах у насінні досліджуваних видів гіркокаштанів відрізняється неістотно, а в антропогенно забруднених зонах iї вміст зменшується в межах до 2 \% у всіх видів.

За вмістом мінеральних елементів в умовно чистих зонах вищі показники були у насінні гіркокаштанів павія і восьмитичинкового і меншими - у кінського звичайного і м'ясо-червоного. У забруднених зонах вміст кальцію і калію знижувався, а натрію збільшувався, особливо у гіркокаштана кінського звичайного. Треба зазначити, що такі зміни мінерального складу свідчать про порушення перебігу процесу метаболізму, особливо у насіння гіркокаштана кінського звичайного.

Важливим показником стійкості рослин за сучасного загального забруднення атмосфери є вміст мікроелементів в їх органах. Зокрема, йдеться про такі мікроелементи, як свинець, кадмій, мідь, цинк та ін., які одночасно є важкими металами і в разі надлишку є потужними токсикантами для рослин.

Визначення рівня вмісту цих мікроелементів дає змогу встановити ступінь порушення нормального процесу метаболізму насіння гіркокаштанів в умовах антропогенно-техногенного забруднення вулиць міста.

Встановлено, що у межах умовно чистих зон насінню гіркокаштана кінського звичайного притаманні максимальні значення серед усіх досліджуваних видів за вмістом міді й цинку, і мінімальні - за вмістом марганцю. Вміст свинцю був практично однаковим у всіх видів. Вміст кадмію у гіркокаштанів кінського, восьмитичинкового і м'ясо-червоного був мізерним. У гіркокаштана павія, окрім кадмію, зафіксовано максимальний вміст заліза, нікелю, але мінімальній рівень хрому (табл. 4).

Табл. 4. Вміст мікроелементів у золі насіння гіркокаштанів

\begin{tabular}{|c|c|c|c|c|c|c|c|c|c|}
\hline \multirow{2}{*}{$\begin{array}{c}\text { Види гірко- } \\
\text { каштанів }\end{array}$} & \multicolumn{7}{|c|}{ Вміст мікроелементів у насінні, в мг/кг золы } \\
\cline { 2 - 9 } & $\mathrm{Cr}$ & $\mathrm{Cu}$ & $\mathrm{Pb}$ & $\mathrm{Mn}$ & $\mathrm{Fe}$ & $\mathrm{Ni}$ & $\mathrm{Cd}$ & $\mathrm{Zn}$ \\
\hline $\begin{array}{c}\text { Гіркокаштан } \\
\text { кінський } \\
\text { звичайний }\end{array}$ & 21,0 & 112,0 & 27,0 & 36,3 & 39,0 & 16,3 & $<1$ & 376,3 \\
\hline $\begin{array}{c}\text { Гіркокаштан } \\
\text { восьмити- } \\
\text { чинковий }\end{array}$ & 17,0 & 42,3 & 24,0 & 38,3 & 52,0 & 23,5 & $<1$ & 103,8 \\
\hline $\begin{array}{c}\text { Гіркокаштан } \\
\text { павія }\end{array}$ & 2,6 & 57,8 & 26,0 & 49,5 & 49,3 & 22,8 & 2 & 311,8 \\
\hline $\begin{array}{c}\text { Гіркокаштан } \\
\text { м'ясо-черво- } \\
\text { ний }\end{array}$ & 27,0 & 59,5 & 26,0 & 45,0 & 32,0 & 13,5 & $<1$ & 399,8 \\
\hline Техногенно-антропогенно 3абруднена зона & \\
\hline $\begin{array}{c}\text { Гіркокаштан } \\
\text { кінський } \\
\text { звичайний }\end{array}$ & 46,0 & 88,9 & 51,5 & 31,4 & 31,3 & 18,8 & 1 & 312,9 \\
\hline $\begin{array}{c}\text { Гіркокаштан } \\
\text { восьмити- } \\
\text { чинковий }\end{array}$ & 34,0 & 46,4 & 50,6 & 46,2 & 53,4 & 22,7 & 1 & 124,7 \\
\hline $\begin{array}{c}\text { Гіркокаштан } \\
\text { павія }\end{array}$ & 3,9 & 63,2 & 56,2 & 52,3 & 51,2 & 23,9 & 4,5 & 334,6 \\
\hline $\begin{array}{c}\text { Гіркокаштан } \\
\text { м'ясо-черво- } \\
\text { ний }\end{array}$ & 39,5 & 64,8 & 50,3 & 47,4 & 36,7 & 14,2 & 1,5 & 205,2 \\
\hline
\end{tabular}

Примітка: <- на межі можливості приладу.

В умовах антропогенно забруднених зон у всіх видів, окрім гіркокаштана павія, стрімко зріс вміст хрому. У насінні усіх видів зріс вміст свинцю і кадмію. Зафіксовано достатньо значне зниження вмісту міді у гіркокаштана кінського звичайного, за одночасного незначного зниження марганцю, заліза, цинку і зростання вмісту нікелю. У решти видів також відбулися зміни вмісту цих мікроелементів, хоча і не такі істотні як у насінні гіркокаштана кінського звичайного.

У гіркокаштана м'ясо-червоного зниження вмісту цинку було досить істотним. Одночасно з цим виявлено незначне підвищення вмісту решти елементів, що, можливо, спричинено наявністю певних компенсаторних механізмів.

Отримані результати свідчать, що в антропогеннотехногенно забруднених зонах відбуваються певні зміни вмісту різних фізіолого-біохімічних показників у на- 
сінні досліджуваних видів гіркокаштанів. При цьому найістотнішими змінами характеризується насіння гіркокаштана кінського звичайного. На нашу думку, це дає змогу констатувати ймовірність наявності порушення гомеостазу клітин внаслідок зміни структури їх мембран і в кінцевому підсумку - порушення окислювально-відновних реакцій клітин.

Підвищення активності перекисного окислення ліпідів (ПОЛ) у стресових умовах свідчить про порушення цілісності мембран і включення інших ключових механізмів клітинної патології. 3 іншого боку, включення ПОЛ $\epsilon$ сигналом для запуску антиоксидантних механізмів, які включають утворення високо- і низькомолекулярних антиоксидантів типу глутатіону і аскорбінової кислоти. Тому підтримка перебігу процесів ПОЛ на оптимальному для клітин рівні є життєво важливим для забезпечення процесів нормального росту і розвитку рослин (Sytnik, Kordium \& Kok, 1969).

Для перевірки цього проаналізовано активність перекисного окисленння ліпідів і вмісту відновленого глутатітону (табл. 5). Згідно з даними цієї таблиці, у насінні всіх досліджуваних видів гіркокаштанів підвищується активність ПОЛ. При цьому максимальне підвищення (більше ніж у два рази) виявлено у насінні гіркокаштана кінського звичайного. Тому, якщо у решти трьох видів гіркокаштанів підвищення ПОЛ можна вважати нормальною сигнальною реакцією рослин на стрес, то у гіркокаштана кінського звичайного це $є$, швидше за все, явним порушенням метаболізму. Підтвердженням останнього є наведені вище результати біохімічних досліджень.

Табл. 5. Активність ПОЛ і вміст відновленого глутатіону в насінні гіркокаштанів

\begin{tabular}{|c|c|c|c|c|}
\hline \multirow{3}{*}{$\begin{array}{c}\text { Вид } \\
\text { гіркокаштана }\end{array}$} & \multicolumn{2}{|c|}{ Активність ПОЛ, в мМ ТБК/г сирої маси } & \multicolumn{2}{|c|}{ Вміст відновленого глутатіону } \\
\hline & $\mathrm{M}^{ \pm \mathrm{m}}$ & $\mathrm{M}^{ \pm \mathrm{m}}$ & \multicolumn{2}{|c|}{ нМ/г сирої маси } \\
\hline & $\begin{array}{c}\text { Умовно } \\
\text { чиста зона }\end{array}$ & $\begin{array}{c}\text { Техногенно-антропогенно } \\
\text { забруднена зона }\end{array}$ & Умовно чиста зона & $\begin{array}{c}\text { Техногенно-антропоген- } \\
\text { но забруднена зона }\end{array}$ \\
\hline Гіркокаштан кінський звичайний & $5,8^{ \pm 0,27}$ & $13,6^{ \pm 0,34}$ & $187,0^{ \pm 4,4}$ & $218,0^{ \pm 3,1}$ \\
\hline Гіркокаштан восьмитичинковий & $6,7^{ \pm 0,18}$ & $8,3^{ \pm 0,21}$ & $341,0^{ \pm 5,6}$ & $597,0^{ \pm 6,4}$ \\
\hline Гіркокаштан павія & $3,9^{ \pm 0,23}$ & $7,8^{ \pm 0,34}$ & $274,0^{ \pm 1,9}$ & $508,0^{ \pm 3,8}$ \\
\hline Гіркокаштан м'ясо-червоний & $7,2^{ \pm 0,41}$ & $9,8^{ \pm 0,48}$ & $314,0^{ \pm 2,5}$ & $517,0^{ \pm 3,6}$ \\
\hline
\end{tabular}

Ще одним підтвердженням цього є динаміка змін вмісту відновленого глутатіону. У гіркокаштанів павія, м'ясо-червоного і восьмитичинкового підвищення вмісту відновленого глутатіону істотне (відповідно 85,4; 64,5 та 75,1 \%), що є нормальною оберненою реакцією на підвищення активності ПОЛ. А у гіркокаштана кінського звичайного за подвійного збільшення активності ПОЛ підвищення вмісту глутатіону становить тільки $16,6 \%$.

Висновки. Наведені вище результати експериментальних досліджень біохімічних показників насіння найпоширеніших у Західному регіоні України у різних видах і типах зелених насаджень гіркокаштанів свідчать про їх індивідуалізацію у межах виду. Ці показники можна використати для визначення стійкості дерев i насаджень різних видів гіркокаштанів як індикатори. При цьому дерева гіркокаштана кінського звичайного у стресових грунтово-кліматичних умовах великого міста 3 додатковим зниженням життєздатності каштановою мінуючою міллю характеризуються найбільшими негативними змінами у метаболізмі порівняно з трьома іншими досліджуваними видами. Отже, за зростання в аналогічних грунтово-кліматичних умовах та за подібного навантаження чинників антропогенно-техногенного впливу, дерева і насадження жовтоквіткового (Aesculus octandra Marsh.) та червоноквіткових видів гіркокаштанів (Aesculus pavia L. i Aesculus carnea Hayne) на сьогодні $є$ стійкішими, ніж дерева і насадження найпоширенішого у регіоні гіркокаштана кінського звичайного (Aesculus hippocastanum L.).

\section{Перелік використаних джерел}

Akimov, F. M., Zerova, M. D., Narolskii, N. B., Nikitenko, G. N., Sviridov, S. V., Kokhanetc, A. M., \& Babidorich, M. M. (2006). Biologiia kashtanovoi miniruiushhei moli C. ohridella (Lepidoptera, Gracillariidae) v Ukraine. Soobshhenie 2. Vestnik zoologii, 40(4), 321-332. [In Russian].

Akimov, I. A., \& Zerova M. D. (2003). Pervoe soobshhenie o poiavlenii v Ukraine kashtanovoi miniruiushhei moli Cameraria ohridella
Desch. \& Dem (Lepidoptera, Gracillariidae) na konskom kashtane obyknovennom. Vestnik zoologii, 37, 3-12. [In Russian].

Akimov, I. A., Zerova, M. D., Narolskyi, N. B., Nikitenko, H. M., Tolkanits, V. H., Svyrodov, S. V., \& Trokoz, V. A. (2003). Fenolohiia kashtanovoi minuiuchoi moli - nebezpechnoho shkidnyka hirkokashtana kinskoho v Ukraini. Ekobezpeka, 5, 43-46. [In Ukrainian].

BSh2.850.012TO. (1974). Fotometr fotoelektricheskii plamennyi PFM. Tekhnicheskoe opisanie i instruktciia po ekspluatatcii. Zagorsk. 44 p. [In Russian].

Debryniuk, Yu. M., Kalinin, M. I., Huz, M. M., \& Shablii, I. V. (1998). Lisove nasinnytstvo: navch. posib. [dlia stud. VNZ]. Lviv: Svit. 432 p. [In Ukrainian].

Demchuk, T. L., Hryhoriuk, I. P., \& Kolomiiets, Yu. V. (2011). Perebudovy fitohormonalnoho statusu v lystkakh hirkokashtana zvychainoho (Aesculus hippocastanum L.), indukovani kashtanovoiu minuiuchoiu milliu (Cameraria ohridella Deschka et Dimic). Botanika ta mikolohiia: problemy i perspektyvy na 2011-2020 roky: mater. Vseukr. nauk. konf., (pp. 260-261). Kyiv. [In Ukrainian].

DSTU 5036:2008. (2009). Nasinnia derev ta kushchiv. Metody vidbyrannia prob, vyznachennia chystoty, masy 1000 nasinyn ta volohosti. Kyiv: Derzhstandart Ukrainy. 46 p. [In Ukrainian].

Ermakov, A. I. (1972). Metody biokhimicheskogo issledovaniia rastenii. (2nd ed.), (pp. 224-225). Leningrad: Kolos. 260 p. [In Russian].

Filonik, I. O., Zamoruieva, L. F., \& Kysla, A. A. (2010). Sklad lipidiv u nasinni hirkokashtana zvychainoho, klena hostrolystoho ta duba zvychainoho v umovakh Dnipropetrovskoho rehionu. Visnyk Dnipropetrovskoho universytetu. Seriia: Biolohiia. Ekolohiia,18(2), 112-119. [In Ukrainian].

Grishko, V. N., \& Syshhikov, D. V. (2012). Funktcionirovanie glutationzavisimoi antioksidantnoi sistemy $i$ ustoichivost rastenii pri deistvii tiazhelykh metallov i ftora. Kyiv: Naukova dumka, 67-68. [In Russian].

Heval, V. F., \& Huz, M. M. (2012). Suchasnyi stan nasinnoho potentsialu hirkokashtana vosmytychynkovoho u Zakhidnomu rehioni Ukrainy. Stan i bioriznomanittia ekosystem Shatskoho Natsionalnoho pryrodnoho parku: mater. nauk. konf., (pp. 7-10), 6-9 veresnia 2012 r., smt Shatsk.Lviv: SPOLOM. [In Ukrainian].

Hryhoriuk, I. P., Mashkovska, S. P., Yavorskyi, P. P., \& Kolesnichenko, O. V. (2004). Biolohiia kashtaniv: navch. posib. Kyiv: Lohos. 380 p. [In Ukrainian].

Kramarets, V. O. (2005). Cameraria orhidella (Lepidoptera, Gracillarideae) - nebezpechnyi shkidnyk kashtana kinskoho. Zeleni miski 
zony - vid problem do rozviazkiv: mater. Mizhnar. nauk. konf., (pp. 88-90), 8-9 cherv. 2004 r. Lviv: Drukarski kunshty. [In Ukrainian].

Kramarets, V. O., \& Kurochka, N. V. (2006). Osoblyvosti rozvytku kashtanovoi minuiuchoi moli Cameraria ohridella (Lepidoptera, Gracillariidae) v zelenykh nasadzhenniakh $\mathrm{m}$. Lvova. Lisivnytstvo Ukrainy $v$ konteksti svitovykh tendentsii rozvytku l/h: tezy dop. Mizhnar. nauk.-prakt. konf., prysv. 150-richchiu vytokiv kaf. lisivnytstva, (pp. 222-223), 20-22 veresnia 2006 r. Lviv. [In Ukrainian].

Liashenko, I. V., Shupranova, L. V., \& Vinnychenko, O. M. (2005). Fizioloho-biokhimichni doslidzhennia hirkokashtanu zvychainoho (Aesculus hippocastanum L.) v umovakh tekhnohennoho zabrudnennia. Suchasni problemy fiziolohii roslyn: tezy Mizhnar. nauk. konf. molodykh vchenykh, (pp. 80-81). Uzhhorod. [In Ukrainian].

Musiienko, M. M., Parshykova, T. V., \& Slavnyi, P. S. (2001). Spektrofotometrychni metody v praktytsi fiziolohii, biokhimii ta ekolohii roslyn. Kyiv: Fitosotsiotsentr. 200 p. [In Ukrainian].

Peterburhskyi, A. V. (1968). Praktykum po ahronomycheskoi khymyy: navch. posib. [dlia stud. VNZ] (pp. 330-331). Moscow: Kolos. [In Ukrainian].

Sytnik, K. M., Kordium, V. A., \& Kok, I. P. (1969). Reguliatornye mekhanizmy kletki. Kyiv: Nauk. dumka. 152 p. [In Russian].

Yavorovskyi, P. P. (2011). Naukovi osnovy rehuliatsii stiikosti roslyn do urbohennykh stresovykh chynnykiv (na prykladi m. Kyieva). Doctoral Dissertation for Agricultural Sciences (06.03.03 - Silvics and forestry). Kyiv. 43 p. [In Ukrainian].

В. Ф. Гевал1, Н. М. Гузь' , В. И. Баранов²

${ }^{1}$ Наииональный лесотехнический университет Украины, г. Львов, Украина Львовский национальный университет им. Ивана Франко, г. Львов, Украина

\section{БИОХИМИЧЕСКИЕ ПОКАЗАТЕЛИ ЖИЗНЕДЕЯТЕЛЬНОСТИ СЕМЯН НАИБОЛЕЕ РАСПРОСТРАНЕННЫХ КОНСКИХ КАШТАНОВ В ЗАПАДНОМ РЕГИОНЕ УКРАИНЫ}

Определены биохимические показатели жизнедеятельности семян конских каштанов с целью поиска стойких против каштановой минирующей моли видов и форм. Для экспериментов в семенной год в условно чистых зонах и местах интенсивного антропогенно-техногенного загрязнения отобраны семена четырех видов конских каштанов. Заготовка семян произведена способом собирания из поверхности земли в период наиболее интенсивного их опадания. Исследовано содержание у семян конских каштанов ряда физиолого-биологических, морфологических и основных биохимических показателей (белка, растворимых углеводов и "сырого жира", золы, макро- и микроэлементов в условиях условно чистых зон и местах антропогенно-техногенного загрязнения. Установлен уровень активности перекисного окисления липидов (ПОЛ) и содержание восстановленного глутатиона. Изученные изменения физиолого-биологических и биохимических показателей свидетельствуют, что по сравнению с тремя другими исследованными видами деревья конского каштана обыкновенного в стрессовых почвенно-климатических условиях большого города, при наличии дополнительного снижения жизнеспособности каштановой минирующей молью характеризируются наибольшими негативными изменениями метаболизма. Это свидетельствует о том, что при произрастании в аналогичных почвенно-климатических условиях и при адекватном воздействии факторов абиотического, биотического и антропогенно-техногенного влияния деревья и насаждения желтоцветного (Aesculus octandra Marsh.) и красноцветных видов конских каштанов (Aesculus pavia L. i Aesculus carnea Hayne) в настоящее время являются более жизнестойкими, чем деревья и насаждения наиболее распространенного в регионе каштана конского обыкновенного (Aesculus hippocastanum L.).

Ключевые слова: конские каштаны; физиолого-биологические, морфологические и основные биохимические показатели семян; содержание микро- и макроэлементов; негативные изменения метаболизма.

V. F. Geval', M. M. Huz', V. I. Baranov'

${ }^{1}$ Ukrainian National Forestry University, Lviv, Ukraine

${ }^{2}$ Ivan Franko National University of Lviv, Lviv, Ukraine

\section{BIOCHEMICAL INDICATORS OF VITALITY OF THE SEEDS OF HORSE CHESTNUT,} COMMON IN THE WESTERN REGION OF UKRAINE

The authors have identified the biochemical indicators of vitality of different kinds of seeds of horse chestnut in order to search for species and forms resistant against the chestnut leaf-mining moth (Cameraria ohridella Desch. \& Dem (Lepidoptera, Gracillariidae)). These parameters were studied for four species of horse chestnut trees by comparing their content in relatively clean areas and in areas of intense anthropogenic and technogenic pollution of the Western region of Ukraine. The ersearch used approved methods of biochemical studies: ash analysis - seeds after combustion in a muffle furnace at a temperature of $450{ }^{\circ} \mathrm{C}$; content "raw" fat - by Rushkovskiy; determination of macro- and microelements - by flame photometry; protein content was determined using Bradford reagent; reduced glutathione - Hryshko method using Ellman's reagent. The content of ash in relatively clean areas in the seeds of the test species of horse chestnut does not differ significantly, and in the contaminated areas anthropogenic decreases to $2 \%$ for all species. According to the content of mineral elements in relatively clean areas of strong performance recorded in the seeds of the horse chestnut trees Pavia and eight stamina and less in ordinary horse and red chestnut. In contaminated areas potassium and calcium content decreased and sodium increased, especially in the horse chestnut. Within conditionally clean zones horse chestnut seed faba ordinary inherent maximum values of all species studied the content of copper and zinc, and the minimum content of manganese. The lead content was almost the same in all species. Cadmium content in horse chestnut, eight stamina and meat-red was scanty. The brown Pavia except cadmium fixed maximum content of iron, nickel, chromium minimum level. The seeds of all the species studied by Buckeyes observed increased activity of lipid peroxidation and reduced glutathione content. The dynamics of biochemical parameters of studied seed by Buckeyes evidence of their individualization within a species. In this case, the horse chestnut trees and the stress in the ordinary soil and climatic conditions, with additional reduction in viability chestnut moth characterized Minira as the most negative change in metabolism compared to the three other species investigated, and consequently less biological resistance.

Keywords: horse chestnuts; physiological and biological, morphological and basic biochemical factors of seed performance; content of micro and macro elements; negative changes of metabolism. 